\title{
Casualties of Aboriginal Displacement in Canada: Children at Risk among the Innu of Labrador
}

\author{
Myriam Denov and Kathryn Campbell
}

\begin{abstract}
The concept of displacement has long been associated with individuals within poor and developing nations, living under conditions of conflict and civil unrest. Conversely, little research attention has been paid to displacement among Aboriginal peoples within the context of wealthy and developed nations such as Canada. This paper explores the consequences of internal displacement for the Innu Nation of Labrador. In particular, it examines how Innu children have become at risk for gasoline sniffing and suicide. The paper concludes by assessing the extent to which the United $\mathrm{Na}$ tions Convention on the Rights of the Child and Canada's Indian Act have been effective in protecting the rights of Innu children. The questionable impact of state responses highlights the need for more effective strategies in order to protect the rights of Innu children.
\end{abstract}

\section{Résumé}

Pendant longtemps, le concept du déplacement a été lié à des gens vivant dans des pays pauvres et en voie de développement, en proie à des conditions de désordre ou de guerres civiles. Inversement, il n'y a pas eu beaucoup de recherches entreprises sur le sujet du déplacement parmi les peuples Autochtones à l'intérieur de pays riches et développés, tel le Canada. Cet article examine les conséquences du déplacement interne sur le peuple Innu du Labrador. En particulier, il se penche sur le cas des enfants Innus à risques, menacés par l'abus de solvants et le suicide. L'article conclut avec une évaluation de l'impacte de la Convention des $\mathrm{Na}$ tions Unies sur les droits des enfants et la Loi sur les Indiens du Canada pour protéger les droits des enfants Innus. L'impacte douteux des mesures adoptées jusqu'ici par l'état, met en exergue la nécessité de trouver des stratégies plus efficaces pour la protection des droits des enfants Innus.

\section{[Aboriginal people] are suffused by a free-floating hostility, the outcome perhaps of the combined ef- fects of territorial disruption, overcrowding and so- cial change...This diffuse hostility has no specific object and appears to be turned inwards in the form of self-destructiveness. ${ }^{1}$}

\section{Introduction}

he concept of displacement has, for the most part, been largely associated with refugees and individuals living under situations of civil unrest, political violence, and armed conflict, particularly within poor and developing nations. ${ }^{2}$ In contrast, few authors have used the concept to explain the forced migration and cultural invasion that have occurred among many Aboriginal populations within wealthy, developed nations such as Canada.

The United Nations Development Program has consistently ranked Canada as one of the best countries in the world in which to live based on the criteria of life expectancy, adult literacy, school enrolment, and economic prosperity. ${ }^{3}$ Given Canada's high standard of living and relatively low level of internal conflict, few would immediately refer to Canadian citizens as typical examples of victims of forced displacement, discrimination, 
or extreme poverty. However, Canada's history of colonization and displacement of its Aboriginal populations tells a story of centuries of domination, discrimination, and assimilation. As a result of the Canadian government's policies involving the forced migration and massive relocations of Aboriginal communities, the concept of displacement is used in this paper to characterize the history and experiences of one Canadian Aboriginal nation. The Innu Nation of Labrador, a traditionally nomadic people who have roamed Nitassinan (Eastern Quebec and Labrador) for over two thousand years, provides a powerful example of an Aboriginal people who have been long-standing victims of cultural invasion and forced displacement within the Canadian context. The history of the Innu reveals two instances of forced internal displacement by the Canadian government and the consequent devastating social, psychological, and economic effects on their communities.

The objective of this paper is to explore the long-term impact of displacement on the Innu people of Labrador. First, the paper examines the community's loss of culture and identity as a result of displacement and forced migration. Second, it explores the community's increasing engagement in self-destructive behaviours such as substance abuse and suicide as consequences of displacement. Third, the paper describes the impact of displacement on those most vulnerable and at risk within the community: Innu children. In particular, the paper examines the relationship between the displacement of the Labrador Innu and current health concerns, including an epidemic of gasoline sniffing and suicide among Innu children. Finally, the paper assesses the extent to which the United Nations Convention on the Rights of the Child and Canada's Act have been effective in protecting the rights of Innu children.

\section{A Brief History of the Innu of Labrador}

Approximately sixteen thousand Innu (formerly known as Montagnais or Naskapi) currently inhabit Nitassinan. Archaeological evidence suggests that the Innu have lived in Nitassinan for at least two thousand years, and some scholars believe that they descended from the first human inhabitants of eastern Canada who moved into this region approximately eight thousand years ago at the end of the last ice age. ${ }^{4}$ The Innu Nation of Labrador comprises approximately fifteen hundred people living in two communities, Sheshatshiu to the south and Utshimassits (Davis Inlet) to the north. Central to the Innu way of life are the herds of caribou that migrate through Nitassinan in the spring and autumn with food, hides for clothing and tents, and bones and antlers for tools or weapons; the caribou remain a central motif of their culture.

By the Second World War virtually all the Innu were, to some extent, involved in the fur trade and were increasingly under the influence of not only the traders, but also the missionaries, government officials, and other non-native people whom they met at the trading posts. The Innu began to spend more time in their coastal settlements. When furs, which provided income, became scarce, poverty and starvation were not uncommon. Government relief was thus provided to the Innu through the Hudson's Bay Company representative or the priest. As time went on, the Innu became increasingly dependent on the church as the intermediary between them and non-Innu who were trying to direct their lives. ${ }^{5}$ Moreover, the priest, who had regular contact with the Innu, held tremendous power and moral authority. The priest is said to have played a pivotal role in encouraging sedentarization among the Innu and the abandonment of their traditional way of life as nomadic hunters. As one Sheshatshiu woman explained:

The priest would come to visit us where we were camped. ... my mother says that the priest got really angry because there was no one living in the community. The Innu people were afraid of the priest. He controlled them and told them what to do. The Innu would still be living in the country if it wasn't for the priest. $^{6}$

At the time of Newfoundland's entry into Confederation in 1949, Innu settlements had long been established in both Sheshatshiu and Davis Inlet. However, these settlements were largely seasonal in nature - families lived in tents and not all of the inhabitants stayed in the settlements year-round. The priests and government representatives continued to pressure the Innu into remaining in permanent settlements. The financial dependency of the Innu on both the church and the Canadian government left them vulnerable to pressure from the government when it finally decided that the Innu must be settled in permanent communities.

According to Samson, Wilson, and Mazower, ${ }^{7}$ the Canadian government set out to achieve two objectives by forcing the Innu to remain in settlements year-round. First, it sought to clear the Innu from their land to allow it to be opened to non-native "development." Second, they intended to prepare the Innu for their new circumstances in settlements with a program of "economic rehabilitation." There was a pervasive belief among government officials that hunting caribou was not "real work" ${ }^{\prime}$ and that the Aboriginal people needed to be integrated into some sort of economic activity. As a result of these government strategies and initiatives, a series of forced migrations and displacements of the Innu of Labrador began in 1948, which has had dire long-term consequences for them. 


\section{The Displacement and Forced Migration of the Innu of Davis Inlet}

Varied definitions exist regarding the concept of displacement, including internal displacement, forced evictions, and population transfers. Stavropoulou ${ }^{9}$ argues that there is little difference among these terms; they all refer to arbitrary, coerced movement of persons, irrespective of their number and irrespective of the extent of the state's involvement in the process. Clearly, the situation of the Innu would fall within the purview of internal displacement. ${ }^{10}$ Having been forced to migrate on two separate occasions, the Innu have suffered physical and cultural upheaval at the hands of the state. While the reasons proffered for these moves were couched in humanitarian terms, there was little, if any, consultation regarding the process and cultural traditions were ignored. Consequently, this forced internal displacement has resulted in a significant erosion of traditional lifestyles, which have been replaced with sedentarization. This in turn has had disastrous consequences for the community. ${ }^{11}$

\section{A. Forced Migration I - 1948}

In 1948, the Innu were moved from Davis Inlet to Nutak, two hundred fifty miles to the north. This move was undertaken without any real consultation with the Innu, and without their consent. To this day, the Innu today still do not understand the rationale for this move. ${ }^{12}$ As Samson, Wilson, and Mazower ${ }^{13}$ note:

There is no single, unambiguous Innu understanding of sedentarization and what it meant: their perception of what happened is embodied, as always, in a series of widely differing accounts reflecting the varied and often chaotic experiences of individuals and families. What is clear however, is that the government made almost no attempt to explain the situation to all the Innu or to obtain their formal consent to settlement.

Although the move was said to be for humanitarian reasons and intended to provide the Innu with greater employment and economic prosperity, there is no evidence that these needs could not already be met in Davis Inlet, or that any government efforts were made to determine the conditions that the Innu would face in Nutak. McRae notes that the relocation of the Innu to Nutak had the more sinister goal of assimilation. ${ }^{14}$ The policy of the Commission of Government was to "make white men" of the Indians and Eskimos. The provincial government saw not only sedentarization itself, but also the government's own work-creation and social assistance schemes as part of a long-term strategy to transform the Innu and assimilate them into Canadian society. ${ }^{15}$ For the Innu, relocation to Nutak provided difficult access to traditional caribou-hunting areas. As a result, in 1949 the community left Nutak of their own volition, and returned to Davis Inlet where they remained until 1967.

\section{B. Forced Migration II - 1967}

In 1967, the Innu of Davis Inlet were relocated by the government a second time, to the site of their present village on Iluikoyak Island. A strong motivation for the move was a government interest in directing the Innu to fishing as an economic activity. There was, once again, no meaningful consultation with the Innu concerning relocation to the new site on Iluikoyak Island and their interests were assumed to be those identified by the priest and government officials who dealt with them. ${ }^{16}$ As one member of the Davis Inlet community remembers: "When we were first told we would be moved to the island, I didn't like the idea... But no one said anything. We just moved." ${ }^{17}$ While houses were built for the Innu at the new site, they lacked the basic amenities of sewage, running water, and furnaces. Moreover, the quality of the building was poor. These conditions have, to this day, never been addressed by the government and many have attested to that fact that the Innu are living in Third World conditions. ${ }^{18}$ These intolerable living conditions have been an important contributor to the poor standard of health in the community and to widespread social dysfunction.

\section{The Impact of Displacement on the Innu of Labrador}

These effects of [displacement] are noticed whether the relocation was for development or administrative purposes...[R]elocation has been a major contributing factor in declining [aboriginal] health, reduced economic opportunities, increased dependence on government and cultural disintegration. ${ }^{19}$

The impact of displacement has been far-reaching in the lives of the Innu of Labrador. Displacement has contributed to the overall loss of Innu culture and identity. It has also increased what is referred to as "culturestress" and self-destructive behaviours.

\section{A. Loss of Culture and Identity}

The forced displacement of the Innu has led to a significant loss of their traditional culture and identity. This loss has been a result of being displaced from their territorial homeland, having their culture, values, and beliefs silenced through the establishment of educational institutions enforcing the "Canadian" curriculum, and through the destruction of the traditional Innu economy. 


\section{Displacement from Territorial Land}

For indigenous peoples' continued existence - throughout the world - land is a prerequisite. It is essential because indigenous people are inextricably related to land: it sustains our spirits and bodies; it determines how our societies develop and operate based on available environmental and natural resources; and our socialization and governance flow from this intimate relationship. ${ }^{20}$

As the above quotation illustrates, the land is of central importance to aboriginal culture, identity, and well-being. Aboriginal people have a unique relationship with the land that guides their daily life and provides them with great meaning. As one Innu man of Sheshatshiu explained: "To reduce the meaning of the word nutshimit to 'the bush' does not describe what it means to us. It is a place where we are at home." ${ }^{21}$ Other places of significance, such as the gravesites of ancestors, locations for ceremonial activities, and geographical features such as mountains and lakes, are said to link a people with its past and its future. ${ }^{22}$ Isolating people from their traditional habitat, therefore, breaks the spiritual relationship with the land that exists within many aboriginal communities.

Not only were the Innu displaced from their homeland in Nitassinan, but in their present location on Iluikoyak Island they are cut off from their hunting grounds, impeding them from carrying out their traditional pursuits. Moreover, in their new environment, the culturally based knowledge that made them self-sufficient in their homeland is not relevant. Whereas they were once skilled, knowledgeable, and confident within the context of the hunting grounds of Nitassinan, in their new environment on Iluikoyak Island, the Innu lack the opportunity to exercise a traditional way of life. As one Innu man from Sheshatshui noted: “... my self, my identity, my own religion is the country. I go to my own school there. There are medicines there that I know about. Out there I am a worker, a hunter, a fisherman, an environmentalist, and a biologist." 23 Displacement among the Innu can thus be seen as part of a painful process of dispossession and alienation of their society from the land and from the cultural and spiritual roots it nurtures, ultimately leading to a sense of powerlessness. ${ }^{24}$

\section{Assimilation through "Education"}

"The best way to destroy a culture is to train its children in another culture." - Innu man from Sheshatshiu ${ }^{25}$

Assimilation through "education" appeared to be one of the most important goals of the government officials and priests advocating the sedentarization of the Innu. Officials believed that through education, the Innu could be "civilized" into mainstream ways of working and seeing the world. Within the village of Sheshatshiu in the early 1950s, Joseph Pirson, an Oblate priest, believed this could be accomplished by sending the younger generation to school, where they would be taught the same curriculum as children elsewhere in Canada. Pirson was aware that keeping children in school would force their parents to abandon hunting and settle down in the village. ${ }^{26}$ Promises of prosperity and hope were given to the Innu. As one Innu woman remembers:

The Innu were told that houses would be built for them and they had to school their children in return. It's like bribing the Innu. The Innu were not to leave the community when their children were being schooled. Not even to go into the country while their land was being destroyed through exploitation...we were told the children would eventually find proper jobs once they finish school. It was never like that. All those promises.... ${ }^{27}$

Furthermore, financial incentives were established whereby families who remained in the village year-round and sent their children to school were eligible to receive monthly government allowance cheques, thus creating a dependence on government assistance. Those who chose to hunt in the bush were not eligible to receive this government support.

Significantly, when schools were initially started, no attempt was made to schedule the school year around the Innu hunting cycles, forcing the Innu to remain in the village during hunting season. Furthermore, the school curriculum was modelled on the mainstream Canadian curriculum and classes were taught in English or French. In the early days in school, Innu children were encouraged to abandon the Innu language. ${ }^{28}$ This has led to the recent situation where young children speak English better than they speak their native Innu language:

The kids don't understand us these days when we use old Innu words...we think they have already entered into the Akanishau [white] culture. That's why they don't understand us...They ask us 'what are you saying? What does that word mean? ${ }^{29}$

The educational system has created a situation whereby it is becoming increasingly difficult for the children to think in the terms and categories of their parents and grandparents.

\section{Destruction of the Traditional Economy}

The displacement of the Innu from their land and way of life also contributed to the destruction of their traditional 
economy. In particular, displacement led to a reduction in the Innu economic base. The Innu had once possessed a large land base and diverse resources in the form of game for food, clothing, and tools, as well as trade with other peoples. Following the forced migration into settlements, the Innu land base and resources became, by comparison, relatively small and limited. ${ }^{30}$

The Innu economic base has also been reduced as a result of loss of land and resources because of flooding through hydroelectric development. Mines, hydroelectric projects, and pulp and paper mills have sprouted up all over the Innu homeland during this century without their consent, ultimately enriching provincial governments and multinationals, and wreaking havoc with Innu lives. ${ }^{31}$ In 1973, the federal government dammed Churchill Falls without consulting the Native people. A large proportion of Innu land, which had sustained them for thousands of years, was flooded without warning and many graves, considered sacred, were destroyed. Churchill Falls, with its annual output of 5.2 million kilowatts, is one of the largest hydroelectric generating stations in the world. Billions of dollars have been made on the project; Hydro-Quebec received 8 per cent of profits, the rest going to other investors and to the province of Newfoundland. ${ }^{32}$ The Innu, who were relocated to new settlements as a result of the flooding, received no compensation. The frustration at losing their land is expressed by this Innu woman:

So much of our land has been taken from us, we are pushed to spend longer and longer periods of time in the community, it's like a gate has been put over us. We're told not to leave the community. They want us to live in shame so people from the outside can say: 'They're just drunken Innu people, they're not worried about their land'...the Innu people are poor while the government and others are making richesses [sic] from our land, they're making lots and lots of money from our land. ${ }^{33}$

The destruction of the traditional economy and the subsequent poverty among the Innu is evident in recent income statistics. In 1996, the average annual income of the Innu of Sheshatshiu was $\$ 10,904$. The average annual income of individuals in Davis Inlet was $\$ 10,612 .{ }^{34}$ Incidentally, during this same year, the average annual income of non-Aboriginal Canadians was $\$ 25,416 .{ }^{35}$

\section{B. Culture Stress and Self-destructive Behaviours}

According to the Royal Commission on Aboriginal Peoples, ${ }^{36}$ the displacement of Aboriginal populations contributes to what is referred to as "culture stress." Culture stress is said to be apparent in societies that have undergone massive, imposed, or uncontrollable change. It is studied primarily in relation to immigrant and indigenous populations, but research on the aftermath of natural disasters such as floods and earthquakes, and on social disasters such as wars, reports similar symptoms of social breakdown. ${ }^{37}$ According to Choosing Life: The Special Report on Suicide among Aboriginal People, ${ }^{38}$ the factors that contribute to culture stress include loss of land, loss of control over living conditions, and restricted economic opportunity, all of which are relevant in the case of the Innu.

In cultures under stress as a result of displacement, normal patterns of behaviour are disrupted and individuals are said to lose confidence in what they know and in their own value as human beings. ${ }^{39}$ They may feel abandoned and bewildered about whether their lives have meaning or purpose. As a result, culture stress is said to play a central role in predisposing Aboriginal people to substance abuse, suicide, and other self-destructive behaviours. In fact, suicide and substance abuse are among the recognized effects of trauma experienced by Aboriginal people. ${ }^{40}$ Many Aboriginal elders maintain that forced relocation and displacement have played a major role in contributing to substance abuse and suicide among Aboriginal people. ${ }^{41}$

\section{Substance Abuse}

Substance abuse is often cited as a response to, and an escape from, the physical and psychological stresses of displacement and the depressing sense of loss and powerlessness among the displaced. ${ }^{42}$ Indeed, there are high levels of alcoholism within Aboriginal communities, and according to several Native leaders, alcohol is the number-one community problem..$^{43}$ Alcohol abuse swept through the Innu communities of Sheshatshiu and Davis Inlet in the 1970s and is now an ingrained feature of daily life. ${ }^{44}$ In Davis Inlet, in 1990, investigators found that between 80 and 85 per cent of residents over fifteen years of age were alcoholic, and that half of these individuals were intoxicated on a daily basis. Substance abuse is said to be a major factor in the high rates of suicide among the Innu. ${ }^{45}$ According to the Innu Band Council's own figures, in 1993 almost a third of all adults in the community of Davis Inlet attempted suicide, generally in alcohol-related incidents. Alcohol abuse among the Innu gained national attention when, in February 1992, six children of Davis Inlet, who had been left unsupervised, burned to death in a house fire while their parents were out drinking. Gasoline sniffing is an equally serious problem in Aboriginal communities. This will be addressed in greater detail below.

\section{Suicide}

A comparison of suicide rates over time suggests that those for Aboriginal people in Canada have been higher 
than for the general Canadian population throughout the last thirty to forty years. ${ }^{46}$ In the past ten to fifteen years, suicide rates for Aboriginal people have been on average three times higher than the Canadian population. ${ }^{47}$ Current statistics place the suicide rate for registered "Indians" at 3.3 times the national average and for Inuit at 3.9 times the national average. ${ }^{48}$

In comparison to the Canadian population as well as to other Aboriginal populations, suicide rates among the Innu are alarmingly high. According to Samson, Wilson, and Mazower, ${ }^{49}$ between 1990 and 1998, there were eight successful suicides in Davis Inlet alone - equivalent to a rate of 178 suicides per 100,000 population, compared to a Canadian rate of 14 per 100,000 . While small in actual numbers, the rates indicate that the Innu of Davis Inlet are almost thirteen times more likely to commit suicide than the general population of Canada. Perhaps more disconcerting is the fact that these figures make the Innu of Davis Inlet the most suicide-ridden people in the world. ${ }^{50}$

Although there are few written documents describing Aboriginal mortality patterns historically, Aboriginal oral tradition tells us that suicide was rare in the time before contact with the Europeans. ${ }^{51}$ Despite the great diversity of Aboriginal populations, they shared a firm belief in spirituality that gave meaning to all life on earth. Most Aboriginal cultures had explicit proscriptions against suicide on the grounds that it contravened natural laws or the design of the Creator. ${ }^{52}$ The high suicide rates among Aboriginal populations and particularly among the Innu can, in part, be related to their history of colonization.

\section{Children at Risk: Intergenerational Trauma and the Plight of Innu Children}

The role of trauma is appearing increasingly in writings about the experiences of Aboriginal peoples, particularly as a metaphor for the consequences of economic and social dependence. ${ }^{53}$ According to Manson et al. (1990), ${ }^{54}$ Manson et al. (1996), ${ }^{55}$ and O'Nell, ${ }^{56}$ there is a disproportionately high percentage of Aboriginal people in the United States who suffer from anxiety disorders, exposure to traumatic events, and posttraumatic stress disorder. Research among the Aboriginal peoples of Australia has demonstrated that long-term exposure to stressor experiences, such as traumatic separation, loss, abuse, dislocation, and dehumanization contributes to a whole host of medical and psychological illnesses. ${ }^{57}$

The effects of displacement and other traumas related to colonization not only have an impact on a single generation of Aboriginal community members, but rather occur intergenerationally. ${ }^{58}$ Indeed, the overall health of Innu children appears to reflect the physical, emotional, and social health of the Innu generally. Within the Innu communities of Sheshatshiu and Davis Inlet, there are extremely high rates of infant mortality. Moreover, gasoline sniffing and suicide among Innu children have become a growing problem.

\section{A. Infant Mortality Rates}

According to statistics from the Assembly of First Nations, ${ }^{59}$ the proportion of Aboriginal sudden infant death syndrome (SIDS) cases has been increasing, while cases of SIDS among the general Canadian population have been decreasing. In fact, an Innu child is between three and seven times more likely to die before the age of five than the average Canadian child, providing another measure of the chasm between the Innu and the rest of Canada. ${ }^{60}$ Even among the Innu of Labrador dramatic differences exist: the rate in Davis Inlet, where there is no sewage or household running water and the nearest hospital can only be reached by airplane, is more than twice that in Sheshatshiu, which has more basic amenities and is within an hour's car drive of the hospital in Goose Bay.

B. Gasoline Sniffing and Suicide among Innu Children The problems of gasoline sniffing and suicide have long affected Canadian Aboriginal communities, and are frequently linked to the effects of colonization, displacement, discrimination, and abuse. ${ }^{61}$ In regard to suicide among Aboriginal youth, the Special Report on Suicide among Aboriginal People notes:

Suicide is a major problem among Aboriginal youth. Racism, loss of culture, physical and mental abuse, family discord, feelings of boredom, loneliness and powerlessness all contribute to the personal pain that leads these young people to choose suicide. Drugs and alcohol abuse tends to exaggerate the problem. ${ }^{62}$

Rates of gasoline sniffing among Aboriginal children appear to be increasing. ${ }^{63}$ Gasoline sniffing was first noticed among Aboriginal populations in the early $1970 \mathrm{~s}$ and has since become more widespread, particularly among Aboriginal populations living on reserves. ${ }^{64}$ In 1975, 62 per cent of Cree and Inuit youth in Northern Quebec revealed that they had sniffed gasoline at least once in the last six months. ${ }^{65}$ Some people were said to use gasoline to calm their infants. Gfellner and Hundleby $^{66}$ and Smart ${ }^{67}$ reported that the use of inhalants was significantly higher among Canadian Aboriginals than non-Aboriginal Canadians.

Persistent gasoline sniffing is a serious and highly dangerous health threat. Medical experts have declared that gasoline sniffing is one of the most dangerous addictions in the world. ${ }^{68}$ Once inhaled, gasoline harms the 
kidneys and liver and inflicts permanent damage on the nervous system and brain, particularly those parts of the brain that control visual coordination, motor skills, and memory. Gasoline sniffing is said to impair cognitive abilities, and chronic gasoline sniffers become dull and clumsy, shake uncontrollably, and may have difficulty walking. According to York, ${ }^{69}$ chronic users often become anemic and suffer weakness in their arms and legs. The emotional and psychological consequences of gasoline sniffing are just as severe: they include feelings of paranoia, isolation and indifference towards oneself and others.

Aside from the obvious health concerns, there appear to be significant social problems that emerge as a result of gasoline sniffing. McGarvey et al. ${ }^{70}$ noted that inhalant-abusing delinquents were significantly more likely to report threatening to hurt people, to have relatives that attempted suicide, and to have committed crimes while intoxicated, than their non-abusing counterparts. Other studies have found a relationship between gasoline sniffing and anti-social, aggressive conduct. ${ }^{71}$

Research indicates that gasoline sniffing appears to be most prevalent among geographically and socially marginalized groups. ${ }^{72}$ According to Fornazzari, ${ }^{73}$ through colonization, the dominant culture has destroyed the traditional economy and social structure of minority groups. These groups therefore adopt self-destructive behaviours, such as gasoline sniffing and alcoholism, because of their loss of identity and traditional way of life. Indeed, this observation appears to reflect the experience of the Innu generally and Innu children specifically. As one Sheshatshiu women explained:

[Gasoline sniffing] has been going on for years and years. ... These children feel that the only way to forget these sort of things [abuse and neglect] is ... gas sniffing. It's not [their] fault the way they are today. I would call them victims of our past. ${ }^{74}$

In the Innu communities of Sheshatshiu and Davis Inlet, the problems of both gasoline sniffing and suicide among Innu children have, over the past ten years, gained national and international attention. ${ }^{75}$ Two recent events in Labrador emphasize the severity of this problem. In January 1993, six Innu children in Davis Inlet barricaded themselves in an unheated shack in temperatures of minus forty degrees and attempted to kill themselves by sniffing gasoline. Television stations across Canada broadcast videotape images of the six children attempting suicide. In response, seventeen children were taken for treatment to Alberta, where they stayed for six months. Upon their return to Davis Inlet, almost all of the children resumed sniffing gasoline within a few weeks. ${ }^{76}$ In Sheshatshiu in the winter of 2000, a group of Innu children aged six to sixteen remained unsupervised in the woods in sub-zero temperatures, sniffing gasoline by an open fire. Weeks before the images of the intoxicated children were captured by Canadian reporters, one eleven- year-old Innu boy had died as a result of playing with a candle while sniffing gasoline.

In response to pleas from parents and Innu leaders at a loss to deal with an epidemic of gasoline sniffing, in January 2001 the Canadian government removed thirtyfive Innu children, aged ten to eighteen, from Labrador to Grace Hospital in St. John's, Newfoundland, for "treatment." The program, which cost the government 5.5 million dollars, was viewed by many as a failure. Youth support workers who served at the hospital claimed that the program lacked structure, and the rapport between staff (who were mostly non-Innu) and Innu children was poor. ${ }^{77}$ Perhaps most importantly, workers claimed there was little or no treatment or counselling aimed at the children's addiction. ${ }^{78}$

Aboriginal communities have had no difficulty explaining to the Royal Commission on Aboriginal Peoples why so many Aboriginal youth are killing and injuring themselves and abusing substances. The causes were said to be in the confusion they feel about their identity, in the absence of opportunity within their communities, and in the bleakness of daily existence where alcohol and drugs sometimes seem to offer the only relief. Like other Aboriginal children, Innu children must deal with a surrounding society that devalues their identity as Aboriginal persons. They may have few supports or role models in families and communities that have been battered by the effects of colonialism and displacement. ${ }^{79}$ Aboriginal people who spoke to the Royal Commission on Aboriginal Peoples ${ }^{80}$ argued consistently that suicide and self-destructive behaviours are the result of a complex fusion of personal, social, and cultural factors that must be seen and understood together - holistically. The effects of displacement and colonization have had dire consequences for the Innu of Labrador. Innu children, those most vulnerable in the community, are continuing to suffer from the past abuses of their people.

The Special Report on Suicide among Aboriginal People $e^{81}$ predicts a coming increase in the number of suicides by Aboriginal youth as the "population bulge" of children now under the age of fifteen enters the vulnerable years of young adulthood. This is clearly an issue for the Innu, as children make up nearly half of the Innu population. In 1996, children aged fourteen and under represented 47 per cent of the population of Sheshatshiu. During this same year, children aged fourteen and under represented 45 per cent of the population of Davis Inlet. ${ }^{82}$ As a result of the large number of Innu children entering adoles- 
cence and young adulthood, the risk of suicide and other self-destructive behaviours may be even greater. It is therefore important to examine current state responses to Aboriginal Canadians and their effectiveness in addressing the problems that are plaguing Innu children.

\section{Examining State and Civil Society Responses: The United Nations Convention on the Rights of the Child, the Indian Act, and Innu Resistance}

This section assesses the extent to which Canada's compliance with the United Nations Convention on the Rights of the Child and Canada's Indian Act have been effective in protecting the rights of Innu children specifically and Aboriginal people generally. It also addresses the collective resistance of the Innu in the face of continued domination by the Canadian government.

\section{A. The United Nations Convention on the Rights of the Child} The establishment of the United Nations Convention on the Rights of the Child (hereafter referred to as the Convention) was a significant achievement regarding the formal and international acknowledgement and recognition of children's rights. As it stood, the Convention was the first of any globally applicable human rights conventions to integrate explicitly the two broad classifications of rights: civil and political; and economic, social, and cultural. ${ }^{83}$ The Convention is based on a "welfare approach," underpinned by three core principles: recognition that children's status is different from that of adults; prioritization of children's welfare; and participation of children in decisions affecting their lives. ${ }^{84}$ Within the Canadian context, the Convention embodied many of the already recognized legal and social principles of Canada's commitment to social justice. However, as a wealthy and prosperous nation with an international reputation for challenging oppressors of the underclasses, Canada clearly falls short when its treatment of Aboriginal peoples is exposed and scrutinized.

As a signatory of the Convention in 1991, the government of Canada, in effect, pledged its commitment to meeting the needs and assigning and respecting the rights of Canadian children regarding their physical, psychological, social, and educational well-being. As part of this commitment, the Canadian government has completed two reports, in 1994 and in 1999, outlining how the country and each specific province has attempted to meet those needs and respect those rights through various practices, policies, and federal and provincial legislations. Article 27, section one of the Convention states that:

1. State parties recognize the right of every child to a standard of living adequate for the child's physical, mental, spiritual, moral and social development.
Closely related to this are other basic needs: the right to the enjoyment of the highest attainable standard of health [article 24(1)]; the right to education [article $28(1)]$ and the right to social security from parents and/or the state [article 27(2)]. While unproblematic in and of themselves with respect to the lives of the majority of Canadian children, the health and education standards are unsatisfactory for poor children and many Aboriginal children. ${ }^{85}$

Furthermore, article 30 states:

In those States in which ethnic, religious or linguistic minorities or persons of indigenous origin exist, a child belonging to such a minority or who is indigenous shall not be denied the right, in community with other members of his or her group, to enjoy his or her own culture, to profess and practise his or her own religion, or to use his or her own language.

In essence, this section of the Convention provides cultural protections for children of minority groups, particularly of Aboriginal communities. ${ }^{86}$ However, the Canadian government entered a "statement of understanding" concerning the Convention's impact upon Aboriginal communities. ${ }^{87}$ This "statement of understanding" constitutes an interpretive guideline, giving great weight to article 30 in interpreting the government's duties towards Aboriginal children. However, the situation of Innu children clearly belies this alleged commitment to Aboriginal children. Forced displacement has had profound effects on the living standards of Innu people. Not only do they live in substandard conditions, in housing provided by the government, the impact of this displacement has effectively increased rates of substance abuse, suicide attempt, and suicides among community members, both young and old. High infant mortality rates, decreased longevity, and increased morbidity reflect the impact of such living conditions. School environments emphasize a Euro-Canadian approach to the world, pay lip service to the Innu language, and function on academic calendars that ignore the hunting season, so important to traditional lifestyles. ${ }^{88}$ These conditions collectively work towards an erosion of the right of Innu children to healthy development.

The role of the Convention in light of respecting these rights begs examination. The Convention, with respect to civil and political rights, does not apply automatically in Canadian courts, as it must first be incorporated into Canadian law. As Toope indicates, the courts in Canada have been inclined to interpret Canadian legislative and administrative actions in light of Canada's international obligations ${ }^{89}$ With respect to economic, social, and cul- 
tural rights, their protection is more complex. It is through social and economic policies, under the control of frequently changing federal and provincial governments, that such rights may be addressed. One danger of an instrument such as the Convention with regard to these rights is that its value becomes solely a symbolic one. Following its submission of the first compliance report on the Convention, the Canadian government received a response from the Committee on the Rights of the Child. The Committee was concerned with the emerging problem of child poverty. Moreover, it went on to state:

17. While recognizing the steps already taken, the Committee notes with concern the special problems still faced by children from vulnerable and disadvantaged groups, such as aboriginal children, with regard to their enjoyment of fundamental rights, including access to housing and education.

The Canadian government's track record with respect to meeting the needs of all Aboriginal people is seriously remiss. When examining the needs and subsequent rights of Aboriginal children, recognized through the Convention, it is highly negligent.

The articulation of a right is only the first step. What often follows are social conflicts in which vested interests and traditional imbalances of power are challenged through various legal, para-legal, and non-legal processes. These conflicts are made all the more difficult in societies that are not culturally attuned to rights discourse..$^{90}$ For an Innu child, the existence of rights protecting his or her access to a safe and healthy development means little if the political will does not exist to ascertain that these rights are respected and enforced. Canada's most recent report regarding the Convention indicates further steps to righting historic injustices through reference to Gathering Strength: Canada's Aboriginal Action Plan. ${ }^{91}$ However, substantial reallocation of resources and political will must follow these commitments if they are to represent real action, and not simply a reiteration of stale political rhetoric.

\section{B. The Indian Act - Equivalency Rights}

While the purpose of the Indian Act is to protect the rights of all Aboriginal or indigenous peoples in Canada, many aspects of it have been continually challenged as being oppressive and paternalistic by various lobby groups advocating for further protection of the rights of Aboriginal people. The federal government itself acknowledges that the legislation provides an inadequate framework for its contemporary relationship with Aboriginal communities. ${ }^{92}$ These problems include a high degree of governmental control over land use decisions; the limited bylaw making powers of bands; band justice enforcement; control of Indian status and band membership; restrictions on band control over Indian finances; and ministerial supervision of band elections. ${ }^{93}$

The relationship between the Innu Nation and provincial and federal governments regarding the application of the Indian Act has been highly contentious. Upon Newfoundland's entry into Confederation in 1949, the government of Canada did not recognize the Innu as Aboriginal peoples under the Indian Act. Instead, it entered into an agreement with the government of Newfoundland, giving it responsibility for the Indian and Eskimo peoples of Labrador, with the federal government providing funding. Given this lack of status, the Innu must negotiate primarily with the provincial government, which has no constitutional mandate with respect to Aboriginal peoples. The government of Newfoundland's policy towards the treatment of Aboriginal people has been explicitly assimilationist, as no category of "citizen" has recognized special rights. ${ }^{94}$

Lack of recognition as Aboriginal/Indigenous peoples under the Indian Act has had devastating consequences for the Innu. Primarily, it has meant that the Innu have not received the range of funding or the level and quality of services that are provided to all other Aboriginal peoples who are registered under the Indian Act and live on reserve land. ${ }^{95}$ This discriminatory treatment constitutes a breach by the government of Canada in its financial obligation to the Innu as Aboriginal people. ${ }^{96}$

The failure of the government of Canada to recognize the constitutional status of the Innu and to deal with them directly as Aboriginal peoples has also meant that they have been denied the opportunity to control their own affairs through self-government. However, the government has sponsored Innu elected Band Councils in the villages, as well as a province-wide organization called the Innu Nation. Whereas these bodies are central in protecting Innu interests, at the same time they are dependent on federal funding which may foster conflicts of interest. ${ }^{97}$ The Innu currently have little say in such matters as health, housing, welfare, education, and policing, and they do not control their own infrastructure and other essential programs. The concept of electing officials is somewhat foreign to many Innu people. Mandatory fluency in French or English, as well as familiarization and ease with western practices of policy making, negotiation, and resource management, clearly are daunting challenges to a people more familiar with living in the bush. By not including the Innu as Aboriginal people, the Indian Act has clearly failed to protect the rights of the Innu and, arguably, has implicitly contributed to the social and economic difficulties in the community. 


\section{Innu Resistance}

The role of the Innu people vis-à-vis their relationship to the Canadian government is an important factor in helping to redress some of the oppressive consequences of past government actions. In Brand's ${ }^{98}$ analysis of the impact of development on the displacement of two distinct groups of Jordanian people, she is able to demonstrate the effect of a strong civil society in mitigating damaging effects. Brand borrows from James Scott's ${ }^{99}$ framework of analysis for understanding the factors that affect how development or modernization projects result in disasters for the people displaced. Scott has demonstrated that, in its quest for greater control over its territory and population, the modern state has devised numerous schemes that, while ostensibly targeting improving the human condition, have nonetheless "gone tragically awry." ${ }^{100}$ Factors that enable this to occur include:

1. implementation of programs aimed at the simplification of administration of territory and population (imposing last names, changing land tenure patterns, forcing sedentarization);

2. adoption by the state of the "high-modern ideology," defined as excessive self-confidence regarding scientific and technical progress;

3. the existence of an authoritarian state willing to use its full power to implement the plans born of the highmodernist ideology;

4. a civil society that lacks the capacity to resist these plans. ${ }^{101}$

The first three factors appear to apply with respect to the internal displacement of the Innu. Displacement occurred for the purposes of development and assimilation, and can be understood as having had destructive effects for them. Clearly, the state sought to claim Innu territory and attempted to control its administration. Successive federal and provincial governments were able to control the Innu of Labrador by resettling them in villages, fettering their attempts at self-government and stifling their land claims. The state also embraced "high modern ideology" in this case by favouring and promoting the flooding of traditional hunting grounds and cemeteries for large-scale development of hydroelectric projects, for which the Innu received no compensation nor any of the profits. At the same time, the state is reinforcing progress by robbing Innu people of the means to follow traditonal lifestyles through forced sedentarization in villages. Not only is the state confident in the righteousness of this process, but it is willing to use its power to implement the change; traditional lifestyles are equated with backwardness and the adoption of western lifestyles as part of village living is considered progressive. This is evident through sanctions imposed on those who demonstrate resistance by enforcing arbitrary hunting rule violations and openly discouraging excessive time spent in traditional practices.
It is with regard to the final factor that the Innu do not closely follow Scott's conceptions. In order for development plans to be completely disastrous, a passive civil society must exist and be incapable of resisting. However, the Innu have demonstrated that they are not altogether passive recipients of modern development and are beginning to find their collective voice. For Brand's purposes, civil society is defined as the

...realm of organized social life that is voluntary, self-generating, (largely) self-supporting, autonomous form the state and bound by a legal order or set of shared rules. It is distinct from "society" in general in that it involves citizens acting collectively in a public sphere to express their interests, passions, and ideas, exchange information, achieve mutual goals, make demands on the state and hold state officials accountable. ${ }^{102}$

The emergence of civil society in Innu culture has been a relatively recent phenomenon. This may be due in part to the reticence of Innu people to "push themselves forward." ${ }^{103}$ Within Innu culture, aggressively voicing dissident opinions is believed to spark conflict and thus should be avoided. However, their passive acceptance of change came to an abrupt halt in 1980 when the first Innu protests began against military activity over low-level flight training at Goose Bay.

NATO air-force exercises, consisting of low-level flight training, air-defence exercises, and bombing practices over Innu land, were intiated in 1979 and continue to be highly problematic. The effects of such practices include loud and sudden screeching noises and deafening booms occurring hundreds of times a day, which have profound effects not only on the Innu people, but also on wildlife. There have been reports that, since these practices have begun, numbers of certain wildlife have been reduced and the behaviour of key species, such as caribou and beaver, have been altered. ${ }^{104}$ The disruptive impact of these practices has been felt most explicitly in the heart of nutshimit (the bush), where traditional practices take place. Moreover, the Innu people have collectively expressed their dissatisfaction with the military training through a series of orchestrated demonstrations, court challenges, and occupations. Additionally, they have been able to garner international support for their cause through effective lobbying and media attention. It is through these actions that Innu citizens of Labrador, functioning as a civil society, have been able to effectively resist "progress" enforced on them by the state, in turn mitigating the effects of development through their continued resistance. In recent years, evi- 
dence of further Innu resistance has been seen against the imposition of restrictions on hunting, on gaining increased control over their children's education, as well as protesting logging road construction, further flooding for hydroelectric development, and expropriation of land for nickel mining. ${ }^{105}$ This continued resistance not only serves to diminish the harms of past actions, but also empowers the Innu to work towards establishing a strong and united community.

\section{Conclusions}

Discussions around the issue of forced displacement are often kept out of human rights discourses, and traditionally such issues have not been debated as human rights problems. ${ }^{106}$ However, by definition, displaced persons have been removed from their home and/or land against their will and have lost the protection of certain basic rights. Moreover, on the international scale, no body exists to monitor displacement as a human rights violation or to monitor the rights of refugees and internally displaced persons. ${ }^{107}$ Given the vulnerable position of many displaced persons, including those living within the borders of their countries of origin, such as the Innu, it would appear that special protections of their rights is essential.

In theory, the Convention could well serve the role of guiding the actions of the Canadian government in protecting the rights of Aboriginal children in Canada. However, in practice, Canada's compliance with the Convention, particularly when considering the reality of Innu children, remains questionable. One obvious way for the Canadian government to improve the plight of the Innu and its children would be to include the Innu of Labrador under the Indian Act, allowing them to gain equivalency rights as Aboriginal people. While clearly not a solution, revising the Indian Act to include the Innu within its mandate, could be a first step in improving the economic and social conditions of Innu communities and empowering the Innu to control their own affairs.

The Innu have demonstrated that they are no longer willing to accept policies and practices of the federal and provincial governments that ignore their fundamental rights. A renewed resistance is beginning to surface regarding a proposal by the provincial government for a possible third forced migration of the people of Davis Inlet. Forced displacement has devastating, long-term effects on many generations of displaced people. It is therefore imperative that the needs of the Innu take precedence. It would be a disservice to Innu children to ignore this opportunity.

\section{Notes}

1. B. Nurcombe, G. Bianchi, J. Money, and J. Cawte, "A Hunger for Stimuli: The Psychosocial Background of Petrol Inhalation," British Journal of Medical Psychology 43 (1970): 367-74.
2. R. Cohen and G. Sanchez-Garzoli, "Internal Displacement in the Americas: Some Distinctive Features," an occasional paper (New York: Brookings CUNY Project on Internal Displacement,2001); F.M. Deng, Specific Groups and Individuals: Mass Exoduses and Displaced Persons, Report of the Representative of the Secretary General on Internally Displaced Persons (Submitted pursuant to the United Nations Committee on Human Rights Resolution 2000/53, 2001); A. Helton, "Displacement and Human Rights: Current Dilemmas in Refugee Protection," Journal of International Affairs 47 (1994): 379-98; M. Stavropoulou, "Displacement and Human Rights: Reflections on UN Practice," Human Rights Quarterly 20 (1998): 515-54.

3. Toronto Star, "Canada Now Third in UN Rating," 3 July 2001.

4. S. Loring, "Keeping Things Whole: Nearly Two Thousand Years of Indian (Innu) Occupation of Northern Labrador," Boreal Forest and Sub-Arctic Archaeology 6 (1988): 157-82.

5. C. Samson, J. Wilson, and J. Mazower, Canada's Tibet: The Killing of the Innu (London: Clement and Foster, 1999).

6. Innu Nation Community Research Project, Gathering Voices: Discovering Our Past, Present, and Future (Nitassinan, 1993).

7. Samson, Wilson and Mazower.

8. M. Wadden, Nitassinan: The Innu Struggle to Reclaim Their Homeland (Vancouver: Douglas and McIntyre, 1991).

9. Stavropoulou.

10. Although this section deals specifically with the experience of forced migration of the Innu of Davis Inlet, it should be noted that the Innu of Sheshatshiu have also suffered from the effects of forced migration.

11. D. McRae, Report on the Complaints of the Innu of Labrador to the Canadian Human Rights Commission (Ottawa: University of Ottawa, 1993).

12. Ibid.

13. Samson, Wilson, and Mazower, 17.

14. McRae.

15. Ibid.

16. Ibid.

17. Innu Nation and the Mushuau Innu Band Council, Gathering Voices: Finding Strength to Help Our Children (Nitassinan: Utshimassits, 1992).

18. Samson, Wilson, and Mazower; Wadden.

19. Royal Commission on Aboriginal Peoples, Report of the Royal Commission on Aboriginal Peoples (Ottawa: Ministry of Supply and Services Canada, 1996).

20. Ibid.

21. Samson, Wilson, and Mazower, 19.

22. Royal Commission on Aboriginal Peoples, 1996.

23. Samson, Wilson, and Mazower, 13.

24 Royal Commission on Aboriginal Peoples, 1996.

25. Samson, Wilson, and Mazower, 23.

26. Wadden.

27. Ibid., 65 .

28. Ibid. 
29. Samson, Wilson, and Mazower, 21.

30. Complete reliance on a traditional lifestyle may not be practical in modern society. However, decisions regarding choice of lifestyle should, ideally, be left to the Innu.

31. Wadden.

32. Wadden.

33. Wadden, 55.

34. Department of Indian and Northen Affairs, 1996.

35. Assembly of First Nations, Fact Sheet: Socio-economic Exclusion of First Nations in Canada (Ottawa: Ministry of Supply and Services, 2001a).

36. Royal Commission on Aboriginal Peoples, 1996.

37. Ibid.

38. Royal Commission on Aboriginal Peoples, Choosing Life: Special Report on Suicide among Aboriginal People (Ottawa: Ministry of Supply and Services Canada, 1995).

39. Royal Commission on Aboriginal Peoples, 1996.

40. S. Manson, L. Ackerson, D. Wiegman, A. Baron, and C. Fleming, "Depressive Symptoms among American Indian Adolescents: Psychometric Characteristics of the Center for Epidemiologic Studies Depression Scale," Psychological Assessment: A Journal of Consulting and Clinical Psychology, 2, no. 3, (1990): 231-37.

41. Royal Commission on Aboriginal Peoples, 1996.

42. Royal Commission on Aboriginal Peoples, 1996.

43. M. Gagne, "The Role of Dependency and Colonialism in Generating Trauma in First Nations Citizens: The James Bay Cree," in Intergenerational Handbook of Multi-generational Legacies of Trauma, ed. Y. Danieli (New York: Plenum, 1998); G. York, The Dispossessed: Life and Death in Native Canada (London: Vintage UK, 1990).

44. Wadden.

45. Samson, Wilson, and Mazower.

46. W. Warry, "Unfinished Dreams: Suicide, Self-determination and Healing in Aboriginal Communities," draft research study (Ottawa: Royal Commission on Aboriginal Peoples, 1993).

47. L. Kirmayer, B. Hayton, M. Malus, V. Jimenez, D. Dufour, C. Quesney, Y. Ternar, T. Yu, and N. Ferarra, "Suicide in Canadian Aboriginal Populations: Emerging Trends in Research and Intervention," draft research study (Ottawa: Royal Commission on Aboriginal Peoples, 1993).

48. Warry.

49. Samson, Wilson, and Mazower.

50. Ibid.

51 Royal Commission on Aboriginal Peoples, 1995, 10.

52. Royal Commission on Aboriginal Peoples, 1995.

53. Gagne.

54. Manson, Ackerson, Wiegman, Baron, and Fleming.

55. S. Manson, J. Beals, T. O’Nell, J. Piaseki, D. Bechtold, and E. Keane, "Wounded Spirits, Ailing Hearts: PTSD and Related Disorders among American Indians," in Ethnographic Aspects of Posttraumatic Stress Disorder: Issues, Research and Clinical Applications, ed. A. Marsella, M. Friedman, E. Gerrity, and R. Scurfield (Washington: American Psychological Association, 1996).

56. T. O’Nell, "Psychiatric Investigations among American Indians and Alaska Natives: A Critical Review," Culture, Medicine and Psychiatry 13 (1989): 58-87.
57. B. Raphael, P. Swan, and N. Martinek, "Intergenerational Aspects of Trauma for Australian Aboriginal People," in Intergenerational Handbook of Multi-generational Legacies of Trauma, ed. Y. Danieli (New York: Plenum, 1998).

58. Gagne.

59. Assembly of First Nations, Fact Sheet: Sudden Infant Death Syndrome (SIDS), (Ottawa: Ministry of Supply and Services, 2001b).

60. Samson, Wilson, and Mazower.

61. Gagne; York.

62. Royal Commission on Aboriginal Peoples, 1995, 8.

63. M. Howard, R. Walker, P. Walker, L. Cottler, and W. Compton, "Inhalant Use among Urban American Indian Youth," Addiction 94, no. 1 (1999): 83-95.

64. Ibid; Gagne.

65. York.

66. B. Gfellner and J. Hundleby, "Patterns of Drug Use among Native and White Adolescents: 1990-1993," Canadian Journal of Public Health 86 (1995): 95-97.

67. R. Smart, "Inhalant Use and Abuse in Canada," in Epidemiology of Inhalant Abuse: An Update, eds. R. Crider and B. Rouse (Rockville, MD: NIDA, 1988).

68. York.

69. York.

70. E. McGarvey, R. Canterbury, and D. Waite, "Delinquency and Family Problems in Incarcerated Adolescents with and without a History of Inhalant Use," Addictive Behaviors 21 (1996): 537-42.

71. W. Compton, L. Cottler, S. Dinwiddie, D. Mager, and G. Asmus, "Inhalant Use: Characteristics and Predictors," American Journal on Addictions 3 (1994): 263-72; B. Reed and P. May, "Inhalant Abuse and Juvenile Delinquency: A Control Study in Albuquerque, NM," International Journal of the Addictions 19 (1984): 789-803.

72. S. Dinwiddie, "Abuse of Inhalants: A Review," Addiction 89 (1994): 925-39; Howard et al.; York.

73. As quoted in York.

74. M. Fox, "Frozen Out," Sydney Morning Herald, 2 February 2001.

75. As noted by Neuwelt et al. (P. Neuwelt, R. Kearns, D. Hunter, and J. Batten, "Ethnicity, Morbidity and Health Service Utilization in Two Labrador Communities," Social Sciences and Medicine 34, no. 2 [1992]: 151-60), native statistics in the province of Newfoundland and Labrador continue to be pooled with those of the rest of the province. This reality ultimately masks the distinctive health experiences of the Innu and explains the difficulty in obtaining statistical data concerning the problem of gas-sniffing and suicide among Innu children.

76. M. MacDonald, "Last of Gas-sniffing Innu Slated to Leave Detox Facility in Newfoundland," The Canadian Press, 23 April 2001.

77. M. Wadden, Interview with Shelagh Rogers, This Morning, Canadian Broadcasting Corporation, 13 March 2001. 
78. B. Sweet, "Staff Say Program Failed at Newfoundland Detox Facility for Gas-sniffing Innu," The Canadian Press, 9 June 2001.

79. Royal Commission on Aboriginal Peoples, 1995, 29.

80. Royal Commission on Aboriginal Peoples, 1996.

81. Royal Commission on Aboriginal Peoples, 1995, 2.

82. Department of Indian and Northern Affairs, 1996.

83. S.J. Toope, "The Convention on the Rights of the Child: Implications for Canada," in Children's Rights: A Comparative Perspective, ed. E. Freeman (Aldershot, UK: Dartmouth Publishing, 1996).

84. D. Haydon and P. Scraton, " 'Condemn a Little More, Understand a Little Less': The Political Context and Rights Implications of the Domestic and European Rulings in the Venables-Thompson case," Journal of Law and Society 27, no. 3 (2000): 416-48.

85. Toope, 39.

86. Toope, 45 .

87. The Canadian government also entered a reservation to section 21 for Aboriginal children. This section ensures that the best interests of children are respected regarding adoptions. The reasons for this reservation relate to the many historical abuses of adoption laws that facilitated the removal of Aboriginal children from their homes.

88. Samson, Wilson, and Mazower, 22.

89. Toope, 39.

90. Toope, 51.

91. Gathering Strength: Canada's Aboriginal Action Plan (Ottawa: Ministry of Supply and Services, 1998).

92. J. Wherrett, The Indian Act: Proposed Modifications (Ottawa: Library of Parliament, 1997).

93. Royal Commission on Aboriginal People, 1996.

94. R. Armitage and J.C. Kennedy, "Redbaiting and Racism on Our Frontier: Military Expansion in Labrador and Quebec," Canadian Review of Sociology and Anthropology 26, no. 5 (1989): 798-817.

95. Wadden.

96. McRae.

97. Samson, Wilson, and Mazower, 28.

98. L.A. Brand, "Displacement for Development: The Impact of Changing State-Society Relations," World Development 29, no. 6 (2001): 961-76.

99. J. Scott, Seeing Like a State: How Certain Schemes to Improve the Human Condition Have Failed (New Haven: Yale University Press, 1998).

100. As quoted in Brand, 961.

101. Scott.

102. L. Diamond, "Rethinking Civil Society: Toward Democratic Consolidation," Journal of Democracy 5, no. 7 (1994): 4-17 [italics original].

103. Samson, Wilson, and Mazower, 17.

104. Ibid., 31.

105. Ibid., 34.

106. Stavropoulou.

107. Ibid.
Myriam Denov holds a Ph.D. in Criminology from the University of Cambridge. She is currently an Assistant Professor in the Department of Criminology, University of Ottawa.

Kathryn Campbell holds a Ph.D. in Criminology from the University of Montreal. She is currently an Assistant Professor in the Department of Criminology, University of Ottawa.

(C) Myriam Denov and Kathryn Campbell, 2002. This open-access work is licensed under a Creative Commons Attribution-NonCommercial 4.0 International License, which permits use, reproduction and distribution in any medium for non-commercial purposes, provided the original author(s) are credited and the original publication in Refuge: Canada's Journal on Refugees is cited. 